\title{
Local anaesthetics or their combination with morphine and/or magnesium sulphate are toxic for equine chondrocytes and synoviocytes in vitro
}

\author{
L. M. Rubio-Martínez ${ }^{1 *}$, E. Rioja' ${ }^{1}$ M. Castro Martins' ${ }^{1}$, S. Wipawee ${ }^{2}$, P. Clegg ${ }^{3}$ and M. J. Peffers ${ }^{3}$
}

\begin{abstract}
Background: Chondrotoxic effects of local anaesthetics are well reported in humans and some animal species but knowledge on their toxic effects on synoviocytes or equine chondrocytes or the effects on cellular production of inflammatory cytokines is limited. The purpose of this study was to evaluate the in vitro effects of local anaesthetics, morphine, magnesium sulphate $\left(\mathrm{MgSO}_{4}\right)$ or their combinations on cell viability and pro-inflammatory cytokine gene expression of equine synoviocytes and chondrocytes.

Equine synoviocytes and cartilage explants harvested from normal joints in a co-culture system were exposed to mepivacaine $(4.4 \mathrm{mg} / \mathrm{ml})$, bupivacaine $(2.2 \mathrm{mg} / \mathrm{ml})$, morphine $(2.85 \mathrm{mg} / \mathrm{ml})$ and $\mathrm{MgSO}_{4}(37 \mathrm{mg} / \mathrm{ml})$ alone or each local anaesthetic plus morphine or $\mathrm{MgSO}_{4}$ or both together. Chondrocyte and synoviocyte cell viability was assessed by CellTiter-Glo Luminescent Cell Viability Assay. Synoviocyte gene expression of IL-1 $\beta$, IL-6 or TNF-a was measured and compared using the $\triangle \triangle C T$ method.

Results: Morphine alone, $\mathrm{MgSO}_{4}$ alone or their combination did not alter cell viability or the expression of IL-1 $\beta$, IL-6 or TNF-a. However, local anaesthetics alone or in combination with morphine and/or $\mathrm{MgSO}_{4}$ reduced cell viability and increased the gene expression of IL-1 $\beta, \mathrm{LL}-6$ or TNF-a. Single short exposure to local anaesthetics is toxic to both chondrocytes and synoviocytes and their combination with morphine and/or $\mathrm{MgSO}_{4}$ enhanced the cytotoxic effects.
\end{abstract}

Conclusions: This in vitro study gives further evidence of the absence of cytotoxic effects of morphine alone, $\mathrm{MgSO}_{4}$ alone or their combination on normal articular tissues. However, local anaesthetics alone or in combination with morphine and/or $\mathrm{MgSO}_{4}$ have cytotoxic effects on equine articular tissues.

Keywords: Local anaesthetic, Morphine, Magnesium sulphate, Chondrocyte, Synoviocyte, Equine

\section{Background}

Intra-articular injections of local anaesthetics are commonly performed in humans and horses to determine sources of pain and as perioperative pain control [1]. Despite their widespread use, there is growing concern over the potential toxicity of these substances and their long-term effects on articular tissue [2, 3]. Chondrotoxic properties of local anaesthetic agents have been reported

\footnotetext{
* Correspondence: luis.rubiomartinez@hotmail.com

'Institute of Veterinary Science, University of Liverpool, Leahurst Campus,

Chester High Road, CH647TE Neston, UK

Full list of author information is available at the end of the article
}

in humans and animals [2, 4-6], but knowledge of their effect on equine chondrocytes is limited [7, 8]. The majority of these studies have investigated their effects on chondrocyte viability, but the effects of local anaesthetics on synoviocytes are still largely unknown. The synovium contributes to nociceptive, inflammatory and degradative responses and therefore it is vital that the effects of intra-articular injections are also studied on the synovium. Recent studies on rabbits and dogs suggest that the toxic effects of local anaesthetic on synoviocytes may affect the onset of chondrolysis associated with intraarticular use of local anaesthetics [9-11]. 
Because of the local anaesthetic related chondrotoxic effects, alternatives for articular analgesia are being sought in humans [3]. Morphine is an opioid that provides excellent articular analgesic and anti-inflammatory effects when administered intra-articularly in humans $[12,13]$ with apparently minimal toxic effects on human and canine chondrocytes [2, 14]. Intra-articular administration of morphine causes analgesia, and reduces swelling and synovial inflammatory markers in horses [15-18], although it was associated with release of large molecular weight proteoglycans into the synovial fluid [19]. Magnesium sulphate $\left(\mathrm{MgSO}_{4}\right)$ is routinely administered intraarticularly to human patients for peri-operative analgesia [20] and does not cause a significant reduction in human chondrocyte viability [21]. Moreover, addition of $\mathrm{MgSO}_{4}$ to local anaesthetics reduced the toxic effects of the latter on human chondrocytes in vitro [22]; and intra-articular administration of $\mathrm{MgSO}_{4}$ attenuated the development of osteoarthritis (OA) in a rat model [23].

We hypothesised that local anaesthetics but not morphine or $\mathrm{MgSO}_{4}$, would produce deleterious effects on chondrocyte and synoviocyte viability and increase the expression of pro-inflammatory cytokines. We further hypothesised that morphine or $\mathrm{MgSO}_{4}$ in combination with a local anaesthetic would prevent the negative effects exerted by local anaesthetics alone.

\section{Methods}

The aim of this study was to evaluate the in vitro effects of clinically-relevant doses of local anaesthetics, morphine, $\mathrm{MgSO}_{4}$ or their combinations on equine chondrocyte and synoviocyte viability and gene expression of pro-inflammatory cytokines in a coculture in vitro model. We hypothesised that local anaesthetics would produce deleterious effects on chondrocyte and synoviocyte viability and increase the expression of pro-inflammatory cytokines. We further hypothesised that morphine and/or $\mathrm{MgSO}_{4}$ in combination with a local anaesthetic would reduce the impact of the negative effects exerted by local anaesthetics alone on cell viability and gene expression of proinflammatory cytokines.

\section{Study design}

An experimental in vitro study was performed on equine synoviocytes and cartilage explants harvested from normal joints and using a co-culture system.

\section{Tissue sample collection}

Tissue samples were obtained from metacarpophalangeal joints of 10 skeletally mature horses (6-10 years old) from an abattoir within $5 \mathrm{~h}$ of slaughter. Synoviocytes were obtained from three horses and articular cartilage samples obtained from seven different horses.
Only horses with grossly normal joints were included in the study.

Under sterile conditions, synovial membrane was harvested from the entire synovial surface of the joint and synoviocytes isolated as previously described [24]. Synoviocytes were cultured in Dulbecco's Modified Eagle Medium (DMEM) (Sigma-Aldrich, Darmstadt, Germany) supplemented with $10 \%$ foetal calf serum (FCS), 100 units $/ \mathrm{ml}$ penicillin, $100 \mu \mathrm{g} / \mathrm{ml}$ streptomycin, L-glutamine $4 \mathrm{mM}$ (all from Invitrogen, Paisley, UK) and $500 \mathrm{ng} / \mathrm{ml}$ amphotericin B (Bio Whittaker, Lonza, San Diego, California, USA), in routine laboratory conditions $\left(37{ }^{\circ} \mathrm{C}, 5 \% \mathrm{O}_{2}\right)$ until $90 \%$ confluent. After treatment with $0.05 \% \mathrm{w} / \mathrm{v}$ trypsin, synoviocytes were passaged and cultured until $90 \%$ confluent. Synoviocytes (passage 2) were then frozen in 10\% DMSO in DMEM complete (DMEM supplemented as above) and stored in liquid nitrogen. Full thickness cartilage was collected from the entire surface of the distal condylar area of the third metacarpus. Cartilage was diced into explants of approximately $2 \mathrm{~mm} \times 2 \mathrm{~mm}$, mixed and placed in complete DMEM complete at $37{ }^{\circ} \mathrm{C}, 5 \% \mathrm{O}_{2}$ for $18 \mathrm{~h}$ to equilibrate.

Synoviocytes from three horses were thawed in a water bath at $37{ }^{\circ} \mathrm{C}$ for $1 \mathrm{~min}$, mixed and suspended in DMEM complete to a final concentration of 50,000 live cells per ml. Synoviocytes were plated in 24-well plates at a concentration of 50,000 cells per well ( 2 wells per group). After equilibration at $37{ }^{\circ} \mathrm{C}, 5 \% \mathrm{O}_{2}$ for $24 \mathrm{~h}$, trans-well inserts $(0.45 \mu \mathrm{m}$ pore, $12 \mathrm{~mm}$; Millicell Cell Culture Inserts PIHA01250; Sigma-Aldrich, Darmstadt, Germany) were located into the wells and cartilage explants from 7 horses were placed separately into the inserts (5 explants per insert) in duplicate. The co-culture system was maintained in an incubator at $37{ }^{\circ} \mathrm{C}, 5 \% \mathrm{O}_{2}$ for $24 \mathrm{~h}$ at which time co-cultures were exposed to different treatments for $2 \mathrm{~h}$ (Table 1). Drugs were diluted in DMEM complete to a total volume of $2 \mathrm{ml}$ per well to achieve the following final concentrations: mepivacaine $4.4 \mathrm{mg} / \mathrm{ml}$, bupivacaine $2.2 \mathrm{mg} / \mathrm{ml}$, morphine $2.85 \mathrm{mg} / \mathrm{ml}$, magnesium sulphate $37 \mathrm{mg} / \mathrm{ml}$. Concentrations were based on the average volume of synovial fluid in the equine metacarpophalangeal joint $(12.5 \mathrm{~mL})$ [25] and the doses commonly used in clinical practice [16, 17, 26-29]. Exposure time $(2 \mathrm{~h})$ was based on the reported half-life for the local anaesthetics in horses [26, 30]. After exposure, the medium containing the different treatments was removed and replaced by DMEM complete and cultured for additional $48 \mathrm{~h}$. At this time synoviocytes and explants were harvested. Cartilage explants were snap-frozen in liquid nitrogen and stored at $-80{ }^{\circ} \mathrm{C}$. Synoviocytes from the same group were released from the wells using $250 \mu \mathrm{L}$ Tri-reagent (Sigma-Aldrich, Darmstadt, Germany) per well for $30 \mathrm{~min}$ and immediately stored at $-80^{\circ} \mathrm{C}$ 
Table 1 Treatment groups

\begin{tabular}{ll}
\hline Group & Treatment \\
\hline 1 & Control \\
3 & Mepivacaine only \\
4 & Mepivacaine + morphine \\
5 & Mepivacaine + MgSO4 \\
6 & Mepivacaine + morphine + MgSO4 \\
7 & Morphine only \\
8 & MgSO4 only \\
9 & Morphine + MgSO4 \\
10 & Bupivacaine only \\
11 & Bupivacaine + morphine \\
12 & Bupivacaine + MgSO4 \\
\hline
\end{tabular}

Treatment groups to which synoviocyte-articular cartilage explant co-cultures were exposed. Concentrations used were mepivacaine $4.4 \mathrm{mg} / \mathrm{ml}$, bupivacaine $2.2 \mathrm{mg} / \mathrm{ml}$, morphine $2.85 \mathrm{mg} / \mathrm{ml}$ and magnesium sulphate $37 \mathrm{mg} / \mathrm{ml}$ diluted in DMEM complete to a total volume of $2 \mathrm{ml}$ per well

\section{Cell viability}

Cell viability was performed on tissues from one well per group. Chondrocytes were recovered after digesting cartilage explants with $1 \mathrm{mg} / \mathrm{ml}$ collagenase II (Worthington Biochemical Corporation, Lakewood, US). Cell viability analysis was performed on synoviocytes and chondrocytes with CellTiter-Glo Luminescent Cell Viability Assay using a Glomax Detection System as per manufacturer instructions (Promega, Wisconsin, US). This assay determines the number of viable cells in culture based on quantification of adenosine triphosphate by luminescence, which signals the presence of metabolically active cells [31, 32].

\section{RNA extraction and Real-time Quantitative Polymerase Chain Reaction (qPCR) analysis}

RNA was extracted from cartilage explants and synoviocytes as previously described [33]. Total RNA concentration was determined using a Nanodrop-2000c (Thermo Fisher Scientific). Complimentary DNA (cDNA) was prepared [33]. Real-time qPCR was used to measure relative gene expression for markers of three pro-inflammatory cytokines: Interleukin 1 beta (IL1 $\beta$ ), Interleukin 6 (IL6) and Tumour Necrosis Factor alpha (TNF $\alpha$ ) compared to the reference gene glyceraldehydes-3-phosphatedhyrogenase (GAPDH) as described previously using SYBR Green technology [33]. Primer sequences are listed in Table 2.

\section{Statistical analysis}

Data were analysed using commercially available statistical software (SPSS, version 22.0, 2013, Chicago, USA). Graphical displays and Anderson-Darling test were used to check for departures from assumptions of normality. Log transformations were applied when data were non-normally distributed. Gene expression data
Table 2 Primer sequences of the reference gene (GAPDH) and pro-inflammatory cytokines IL1 $\beta$, IL6 and TNFa used in the

\begin{tabular}{llll} 
study & & & \\
\hline Gene & $\begin{array}{l}\text { GeneBank } \\
\text { Accession }\end{array}$ & Direction & Primer Sequence (5'-3') \\
\hline GAPDH & NM_001163856 & Forward & GCATCGTGGAGGGACTCA \\
IL-1 $\beta$ & NM_001317261 & Forward & GCCACATCTTCCCAGAGG \\
& Reverse & GGCATTGATTAGACAACAGTGAA \\
IL-6 & NM_001082496 & Forward & CTGCTCCTCGTGATGGCTAC \\
& & Reverse & CCGAGGATGTACTTAATGTGCTG \\
TNF-a & NM_001081819 & Forward & CCTTCCACTCAATCAACCCTCT \\
& & Reverse & CACGCCCACTCAGCCACT \\
\hline
\end{tabular}

Primer sequences of the reference gene (GAPDH) and proinflammatory cytokines IL $1 \beta$, IL6 and TNFa used in the study

were normalised to the reference gene using the $\Delta \Delta \mathrm{CT}$ method [34] and statistical analysis applied to the $2^{\wedge}-\Delta C T$ values. General linear models with Dunnet's comparisons with control group were performed. Significance was considered when $p<0.05$. Gene expression results were normalised to the control group.

\section{Results}

\section{Cell viability}

Raw data of cell vaiability are provided in Additional file 1. The effects of different treatments on synoviocyte and chondrocyte viability are presented in Figs. 1 and 2

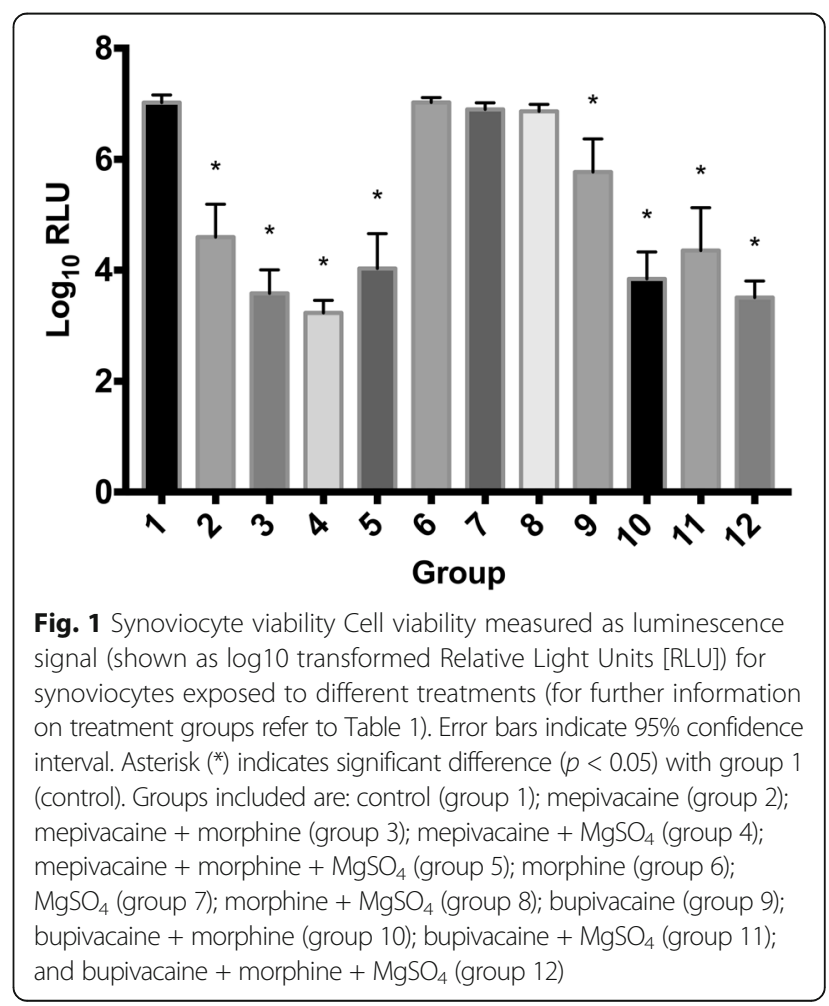




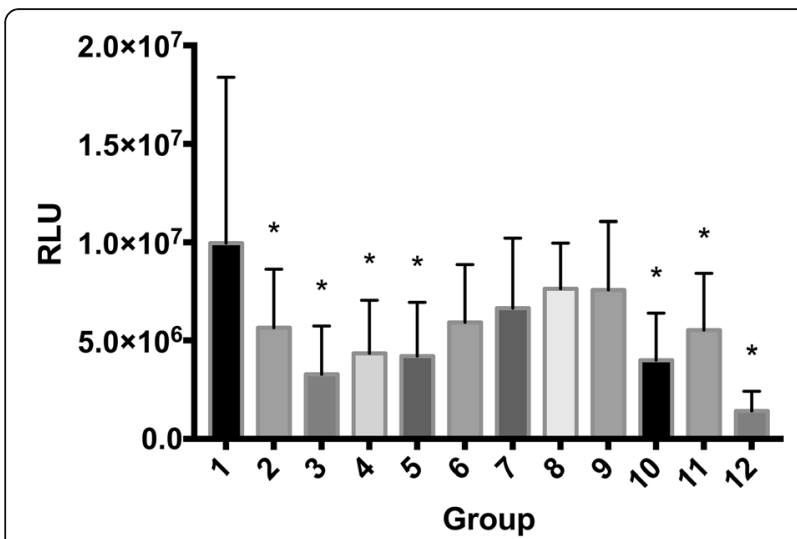

Fig. 2 Chondrocyte viability Cell viability measured as luminescence signal (mean values of Relative Light Units [RLU]) for chondrocytes exposed to different treatment groups (for further information on treatment groups refer to Table 1). Error bars indicate 95\% confidence interval. Asterisk $\left(^{*}\right)$ indicates significant difference $(p<0.05)$ with group 1 (control). Groups included are: control (group 1); mepivacaine (group 2); mepivacaine + morphine (group 3); mepivacaine $+\mathrm{MgSO}_{4}$ (group 4); mepivacaine + morphine $+\mathrm{MgSO}_{4}$ (group 5); morphine (group 6); $\mathrm{MgSO}_{4}$ (group 7); morphine $+\mathrm{MgSO}_{4}$ (group 8); bupivacaine (group 9); bupivacaine + morphine (group 10); bupivacaine $+\mathrm{MgSO}_{4}$ (group 11); and bupivacaine + morphine $+\mathrm{MgSO}_{4}$ (group 12)

respectively. Compared with control group, chondrocyte or synoviocyte viability did not change in groups exposed to morphine alone, $\mathrm{MgSO}_{4}$ alone or morphine and $\mathrm{MgSO}_{4}$ in combination. Chondrocyte viability was significantly reduced in chondrocytes exposed mepivacaine alone or in combination with morphine and/or $\mathrm{MgSO}_{4}$ (groups 2, 3, 4 and 5). Exposure to bupivacaine alone did not reduce chondrocyte viability in comparison with control group; however, chondrocyte viability was significantly reduced in groups exposed to combinations of bupivacaine with either morphine or $\mathrm{MgSO}_{4}$ or both combines (groups 10, 11 and 12). Synoviocyte viability was reduced in all groups exposed to either local anaesthetic (mepivacaine or bupivacaine), and any of their combinations with morphine and/or $\mathrm{MgSO}_{4}$. (groups 2, 3, 4, 5, 9, 10, 11 and 12).

\section{Real-time qPCR}

Raw data on gene expression are provided in Additional file 1 . Treatment with morphine, $\mathrm{MgSO}_{4}$ or their combination did not have an effect on synoviocyte gene expression of IL-1 $\beta$, IL- 6 or TNF- $\alpha$. Exposure to mepivacaine alone (group 2) increased expression of IL$1 \beta$, IL6 and TNF- $\alpha$, while exposure to bupivacaine alone (group 9) only significantly increased expression of IL6. Combination of either mepivacaine or bupivacaine with morphine, $\mathrm{MgSO}_{4}$, or both (groups 3, 4, 5, 10, 11 and 12) increased expression of IL- $1 \beta$, IL- 6 and TNF- $\alpha$ (Figs.

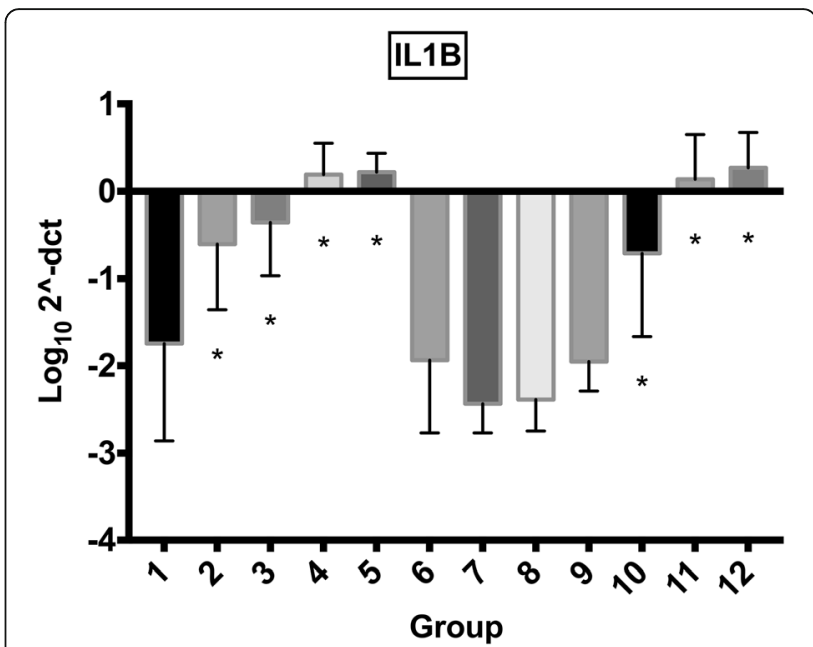

Fig. 3 Synoviocyte IL1 $\beta$ gene expression IL1 $\beta$ gene expression (mean $\log _{10} 2 \wedge-\Delta C T$ ) for synoviocytes exposed to different treatment groups (for further information on treatment groups refer to Table 1). Error bars indicate $95 \%$ confidence interval. Asterisk (*) indicates significant difference $(p<0.05)$ with group 1 (control). Groups included are: control (group 1); mepivacaine (group 2); mepivacaine + morphine (group 3); mepivacaine $+\mathrm{MgSO}_{4}$ (group 4); mepivacaine + morphine $+\mathrm{MgSO}_{4}$ (group 5); morphine (group 6); $\mathrm{MgSO}_{4}$ (group 7); morphine + $\mathrm{MgSO}_{4}$ (group 8); bupivacaine (group 9); bupivacaine + morphine (group 10); bupivacaine $+\mathrm{MgSO}_{4}$ (group 11); and bupivacaine + morphine $+\mathrm{MgSO}_{4}$ (group 12).

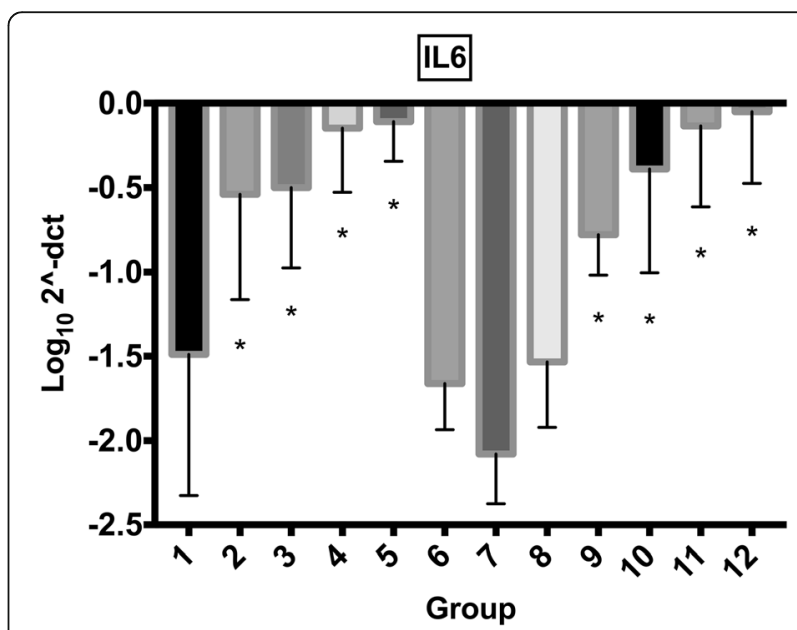

Fig. 4 Synoviocyte IL6 gene expression IL6 gene expression (mean $\log _{10} 2 \wedge-\Delta C T$ ) for synoviocytes exposed to different treatment groups (for further information on treatment groups refer to Table 1). Error bars indicate $95 \%$ confidence interval. Asterisk $\left(^{*}\right)$ indicates significant difference $(p<0.05)$ with group 1 (control). Groups included are: control (group 1); mepivacaine (group 2); mepivacaine + morphine (group 3); mepivacaine $+\mathrm{MgSO}_{4}$ (group 4); mepivacaine + morphine $+\mathrm{MgSO}_{4}$ (group 5); morphine (group 6); $\mathrm{MgSO}_{4}$ (group 7); morphine + $\mathrm{MgSO}_{4}$ (group 8); bupivacaine (group 9); bupivacaine + morphine (group 10); bupivacaine $+\mathrm{MgSO}_{4}$ (group 11); and bupivacaine + morphine $+\mathrm{MgSO}_{4}$ (group 12). 


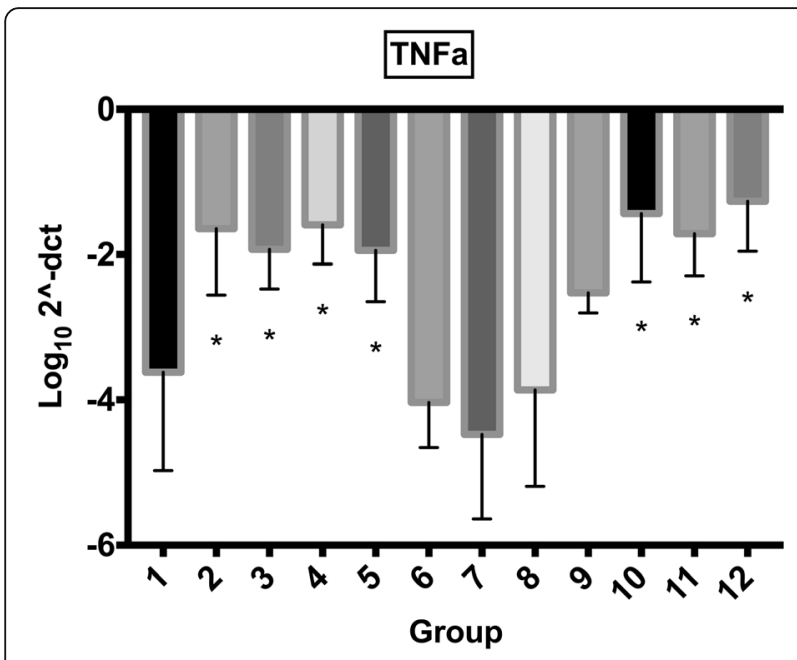

Fig. 5 Synoviocyte TNFa gene expression (mean $\log _{10} 2^{\wedge}-\Delta C T$ ) for synoviocytes exposed to different treatment groups (for further information on treatment groups refer to Table 1). Error bars indicate 95\% confidence interval. Asterisk $\left(^{*}\right)$ indicates significant difference $(p<0.05)$ with group 1 (control). Groups included are: control (group 1); mepivacaine (group 2); mepivacaine + morphine (group 3); mepivacaine $+\mathrm{MgSO}_{4}$ (group 4); mepivacaine + morphine $+\mathrm{MgSO}_{4}$ (group 5); morphine (group 6); $\mathrm{MgSO}_{4}$ (group 7); morphine $+\mathrm{MgSO}_{4}$ (group 8); bupivacaine (group 9); bupivacaine + morphine (group 10); bupivacaine $+\mathrm{MgSO}_{4}$ (group 11); and bupivacaine + morphine + $\mathrm{MgSO}_{4}$ (group 12)

3, 4, 5). Gene expression from cartilage explants did not yield consistent amount of RNA for downstream qRTPCR.

\section{Discussion}

Chondrotoxic effects of local anaesthetics are reported in the literature and results of this study confirm that a single short exposure to local anaesthetics causes significant articular cytotoxic effects characterised by decreased viability of both equine synoviocytes and chondrocytes. These effects were not counteracted by the addition of morphine and/or $\mathrm{MgSO}_{4}$. Except for the mepivacaine effect on TNF- $\alpha$ expression, local anaesthetics alone, as well as morphine alone, $\mathrm{MgSO}_{4}$ alone, or morphine and $\mathrm{MgSO}_{4}$ combined, did not increase the expression of proinflammatory cytokines by synoviocytes; however, the proinflammatory cytokines expression were increased when local anaesthetics were combined with morphine and/or $\mathrm{MgSO}_{4}$.

The present study demonstrates that bupivacaine at a concentration of $0.22 \%$ is harmful for articular equine synoviocytes but its negative effects are less pronounced on chondrocytes. A protective effect from the existence of intact extracellular matrix on chondrocytes from the cartilage explant has been previously suggested [6, 14], although this was recently questioned on an experimental canine model [10]. Local anaesthetics have drug-, dose- and time-dependent cytotoxic effects [5, 10, 35-37]. Bupivacaine $0.0625 \%$ did not cause cell death in canine cartilage and synovium explants [10] and varying toxicity has been observed for bupivacaine concentrations in the range of $0.125-0.25 \%[2,5,10,35]$. Bupivacaine concentrations $\geq 0.5 \%$ have consistently been reported to exert toxic effects on human and animal chondrocytes [5, 35], including horses [7] but interestingly did not affect the viability of rabbit type B synoviocytes in monolayer [11]. Different species sensitivities, methodologies or cell lines may explain different results between studies. Mepivacaine is less frequently administered as an intra-articular analgesic in people and there are fewer studies investigating its effects on articular cells. In contrast to our study, mepivacaine was less toxic than bupivacaine on human [35] and equine [7] chondrocytes on monolayer cultures. However, the bupivacaine concentration used in the present study was lower than in previous studies and has been previously associated with chondrotoxic effects on human cartilage [35] and equine chondrocytes [38]. Mepivacaine is commonly administered intra-articularly in horses at doses similar to that in the present study and temporary synovitis has occasionally been reported [27].

Few studies have investigated the effects of local anaesthetics on the production of inflammatory molecules by articular tissues. Following exposure to bupivacaine a decrease in nitric oxide and $\mathrm{PGE}_{2}$ concentrations was observed in an IL-1-treated co-culture explant model; and that was suggested to be the result of the lack of viable cells remaining after the exposure [2]. However, in our study increased expression of IL1- $\beta$, IL6 or TNF- $\alpha$ was observed despite decreased viability

Intra-articular administration of morphine or $\mathrm{MgSO}_{4}$ produces analgesia without clinical evidence of adverse effects in people [12, 13, 20, 39-41]. The present study corroborates the absence of deleterious effects of morphine or $\mathrm{MgSO}_{4}$ on canine human and canine chondrocyte viability in vitro $[2,14,21,22]$, and extends this absence of toxicity to synoviocytes. Furthermore, the combination of morphine and $\mathrm{MgSO}_{4}$ did not have negative effects on cell viability, which warrants investigation of the potential analgesic effect of the combination in vivo. In addition, no effects on expression of pro-inflammatory cytokines were observed when tissues were exposed to morphine and/or $\mathrm{MgSO}_{4}$. Antiinflammatory effects of opioids have been reported after systemic or local administration. Morphine exposure of IL-1-treated cartilage explants decreased nitric oxide and $\mathrm{PGE}_{2}$ production [2]. Intra-articular administration of morphine reduced nucleated cell count in synovial fluid of chronic arthritis patients [42] and serum amyloid A and total protein levels in horses with experimentally-induced synovitis [15]. Anti-inflammatory effects of magnesium have also been recognised. Low magnesium promotes 
inflammation and up-regulates IL1 $\alpha$ and IL6 production in endothelial cells [43] while magnesium supplementation attenuated the development of OA [23] and rheumatoid arthritis (RA) [44]. $\mathrm{MgSO}_{4}$ acts on $N$-methyl-Daspartate receptors and although the present study did not include an OA or RA model, $N$-methyl-D-aspartate receptors involved in the development of OA and RA are also present in normal human and mouse articular chondrocytes [45]. Results of this study support the clinical use of morphine and warrant further investigation on $\mathrm{MgSO}_{4}$ as intra-articular analgesic drugs in horses and other species.

Addition of $\mathrm{MgSO}_{4}$ to local anaesthetics counteracted harmful effects on human chondrocyte viability in vitro [22] and we aimed to determine if the same was true in a synoviocyte and cartilage explant co-culture model. However, the addition of morphine, $\mathrm{MgSO}_{4}$ or both to mepivacaine or bupivacaine did not counteract cell death caused by mepivacaine and furthermore, decreased chondrocyte viability in comparison with the control group when combined with bupivacaine. Combination of either local anaesthetic with morphine and/ or $\mathrm{MgSO}_{4}$ also enhanced the synoviocyte expression of IL1 $\beta$, IL6 and TNF $\alpha$. The reasons for the enhanced toxicity of the drug combinations are unclear. The mechanisms of action of local anaesthetics, morphine and $\mathrm{MgSO}_{4}$ differ. The cytotoxic effects of local anaesthetics are related to a concentration-dependent mitochondrial depolarization with subsequent alteration in transmembrane potential and cell death [46]. Osmolality-related cytotoxicity has been observed with high concentrations of magnesium $(500 \mathrm{mg} / \mathrm{ml})$ [22] but the concentration used in the present study was $37 \mathrm{mg} / \mathrm{ml}$. Interaction between molecules or their combination with the culture medium or changes in the $\mathrm{pH}$ of the environment may be involved [47]. A time-dependent increased chondrotoxicity has been observed for the combination of corticosteroid and local anaesthetics [48]. The $\mathrm{pH}$ of the treatment solutions in the present study were nor determined and buffer solutions were not used; however, low $\mathrm{pH}$ was not the cause for decreased viability of bovine chondrocytes $[1,49]$ and addition of buffering solution can increase chondrotoxicity [47]. Chemical incompatibility between the anaesthetic solution and culture medium leading to crystal formation and high cell death rates has been suggested by some authors [1,7]; however, precipitation was not observed in the present or other studies [2, 10,38]. Although combination of local anaesthetics and $\mathrm{MgSO}_{4}$ are being administered clinically into joints without reported clinical side effects $[20,50]$ further research into the chemical compatibility or interactions between drugs is warranted.

The present study has a number of limitations. A coculture equine model was used to allow evaluations of both cartilage and synovium components as many inflammatory mediators and analgesic receptors are found in the synovium, and synoviocytes have important roles in maintaining articular health and participating in pathophysiological processes [51, 52]. However, results from this in vitro study may not be the same in vivo. Use of synovial explants $[2,10]$ could have enhanced the system although recent studies support the comparability of explants and monolayer cultures to assess cytotoxicity $[2,10]$. The preferential type of synoviocyte present in the culture is uncertain and a mixture of both macrophage-like and fibroblast-like synoviocytes is suspected in this study as they were frozen at passage 2 [52]. Drug concentrations and duration of exposure were based on clinically used doses, joint volume and pharmacokinetics in horses. However, the drug concentrations remained constant during the $2 \mathrm{~h}$ exposure, which could be interpreted as a relative overdose as clearance of the drug is expected to occur already within this time in the live animal. The horse is an accepted translational models of naturallyoccurring osteoarthritis [53] but drug effects can differ between species. Normal articular tissues were used and more severe chondrotoxic effects are expected on degenerative versus normal cartilage [35]. The reasons for the poor RNA extraction from cartilage explants are uncertain. This methodology has been used successfully in other studies but equine mature articular cartilage is relatively acellular and we used small size explants. Previous studies in our lab have yielded $1 \mu \mathrm{g}$ of RNA from the cartilage harvested from both third metacarpal condyles in adult horses (Peffers M.J. Unpublished data). The use of isolated chondrocytes, larger size or higher number of cartilage explants, or use of a different methodology may have yielded gene expression data from the cartilage explants. Quantification of adenosine triphosphate by luminescence has been shown reliable method to assess cell viability $[14,31]$.

\section{Conclusions}

The present study corroborate the toxic effects of single short exposure to local anaesthetics on both equine chondrocytes and synoviocytes using an in vitro coculture model, with more severe effects observed for mepivacaine than bupivacaine. It also provides evidence that synoviocytes respond to drugs commonly administered intra-articularly, which warrants further investigation. The present study indicates that morphine and $\mathrm{MgSO}_{4}$ are not toxic to synoviocytes when exposed either alone or in combination, which supports the clinical use of morphine and warrants further investigation of $\mathrm{MgSO}_{4}$ as intra-articular analgesic drugs in horses and other species. However, further investigation into drug incompatibilities is required as combinations 
of either mepivacaine or bupivacaine with morphine, $\mathrm{MgSO}_{4}$ or both did not alleviate any detrimental effects from the local anaesthetics, but actually caused cell death and increased expression of pro-inflammatory enzymes.

\section{Additional file}

Additional file 1: Raw data on chondrocyte and synoviocyte viability and synoviocyte gene expression. (XLSX 18 kb)

\section{Abbreviations}

CDNA: Complimentary deoxyribonucleic acid; DMSO: Dimethyl sulfoxide; FCS: Foetal calf Serum; GAPDH: Glyceraldehyde-3-phosphatedhyrogenase; IL13: Interleukin 13; IL-6: Interleukin 6; $\mathrm{MgSO}_{4}$ : Magnesium sulphate;

OA: Osteoarthritis; qRT-PCR: Real-time quantitative polymerase chain reaction; TNF-a: Tumour necrosis factor a

\section{Acknowledgements}

We wish to thank lan Richards for his contribution in the acquisition of data. None of the authors have conflicts of interests.

\section{Funding}

This study was funded by the Horserace Betting Levy Board (SPrj015). Mandy Peffers is funded through a Wellcome Trust Clinical Intermediate Fellowship (107471). Funding bodies did not take part in the study design or conclusion of the study.

\section{Availability of data and materials}

All data generated and analysed during this study are included in this published article and its supplementary information files.

\section{Authors' contributions}

LMRM, MJP, ER and PC participated in the design of the study and the experiments and interpretation of the data. LRM, MCM and SW participated in the design of the study, performing the majority of the experiments and interpretation of data. LRM and ER performed statistical analysis and interpretation of the data. MJP and PC supervised all the experiments. All authors read and approved the final manuscript.

\section{Ethics approval and consent to participate}

No samples were obtained from equine patients. Tissue samples were collected from the abattoir which are considered a by-product of the agricultural industry. Specifically, the Animal (Scientific Procedures) Act 1986, Schedule 2, does not define collection from these sources as scientific procedures. Ethical approval was therefore not required for this study.

\section{Consent for publication}

Not applicable.

\section{Competing interests}

All authors declare that they have no competing interests.

\section{Publisher's Note}

Springer Nature remains neutral with regard to jurisdictional claims in published maps and institutional affiliations.

\section{Author details}

'Institute of Veterinary Science, University of Liverpool, Leahurst Campus, Chester High Road, CH647TE Neston, UK. ${ }^{2}$ Faculty of Veterinary Science, Rajamangala University of Technology Srivijaya (Thailand) and Institute of Aging and Chronic Disease, University of Liverpool, Liverpool, UK. Institute of Aging and Chronic Disease, University of Liverpool, Liverpool, UK.
Received: 17 February 2017 Accepted: 30 October 2017

Published online: 07 November 2017

\section{References}

1. Bogatch MT, Ferachi DG, Kyle B, Popinchalk S, Howell MH, Ge D, You Z, Savoie FH. Is chemical incompatibility responsible for chondrocyte death induced by local anesthetics? Am J Sports Med. 2010:38(3):520-6.

2. Anz A, Smith MJ, Stoker A, Linville C, Markway H, Branson K, Cook JL. The effect of bupivacaine and morphine in a coculture model of diarthrodial joints. Arthroscopy. 2009;25(3):225-31

3. Gulihar A, Robati S, Twaii H, Salih A, Taylor GJ. Articular cartilage and local anaesthetic: A systematic review of the current literature. J Orthop. 2015: 12(Suppl 2):S200-10.

4. Dragoo JL, Braun HJ, Kim HJ, Phan HD, Golish SR. The in vitro chondrotoxicity of single-dose local anesthetics. Am J Sports Med. 2012:40(4):794-9.

5. Chu CR, Izzo NJ, Coyle CH, Papas NE, Logar A. The in vitro effects of bupivacaine on articular chondrocytes. J Bone Joint Surg Br. 2008;90(6): 814-20

6. Chu CR, Izzo NJ, Papas NE, Fu FH. In vitro exposure to $0.5 \%$ bupivacaine is cytotoxic to bovine articular chondrocytes. Arthroscopy. 2006;22(7):693-9.

7. Park J, Sutradhar BC, Hong G, Choi SH, Kim G. Comparison of the cytotoxic effects of bupivacaine, lidocaine, and mepivacaine in equine articular chondrocytes. Vet Anaesth Analg. 2011;38(2):127-33.

8. Piat P, Richard H, Beauchamp G, Laverty S. In vivo effects of a single intraarticular injection of $2 \%$ lidocaine or $0.5 \%$ bupivacaine on articular cartilage of normal horses. Vet Surg. 2012:41(8):1002-10.

9. Sherman SL, James C, Stoker AM, Cook CR, Khazai RS, Flood DL, Cook JL. In Vivo Toxicity of Local Anesthetics and Corticosteroids on Chondrocyte and Synoviocyte Viability and Metabolism. Cartilage. 2015;6(2):106-12.

10. Sherman SL, Khazai RS, James CH, Stoker AM, Flood DL, Cook JL. In Vitro Toxicity of Local Anesthetics and Corticosteroids on Chondrocyte and Synoviocyte Viability and Metabolism. Cartilage. 2015;6(4):233-40.

11. Braun HJ, Busfield BT, Kim HJ, Scuderi GJ, Dragoo JL. The effect of local anaesthetics on synoviocytes: a possible indirect mechanism of chondrolysis. Knee Surg Sports Traumatol Arthrosc. 2013;21(6):1468-74.

12. Grabowska-Gawel A, Gawel K, Hagner W, Bilinski PJ. Morphine or bupivacaine in controlling postoperative pain in patients subjected to knee joint arthroscopy. Ortop Traumatol Rehabil. 2003;5(6):758-62.

13. Kalso E, Smith L, McQuay HJ, Andrew Moore R. No pain, no gain: clinical excellence and scientific rigour-lessons learned from IA morphine. Pain. 2002:98(3):269-75

14. Ickert I, Herten M, Vogl M, Ziskoven C, Zilkens C, Krauspe R, Kircher J. Opioids as an alternative to amide-type local anaesthetics for intra-articular application. Knee Surg Sports Traumatol Arthrosc. 2015;23(9):2674-81.

15. Lindegaard C, Gleerup KB, Thomsen MH, Martinussen T, Jacobsen S, Andersen PH. Anti-inflammatory effects of intra-articular administration of morphine in horses with experimentally induced synovitis. Am J Vet Res. 2010:71(1):69-75.

16. Lindegaard C, Thomsen MH, Larsen S, Andersen PH. Analgesic efficacy of intra-articular morphine in experimentally induced radiocarpal synovitis in horses. Vet Anaesth Analg. 2010;37(2):171-85.

17. Santos $L C$, de Moraes AN, Saito ME. Effects of intraarticular ropivacaine and morphine on lipopolysaccharide-induced synovitis in horses. Vet Anaesth Analg. 2009:36(3):280-6

18. van Loon JP, de Grauw JC, van Dierendonck M, L'Ami JJ, Back W, van Weeren PR. Intra-articular opioid analgesia is effective in reducing pain and inflammation in an equine LPS induced synovitis model. Equine Vet J. 2010; 42(5):412-9.

19. Tulamo RM, Raekallio M, Taylor P, Johnson CB, Salonen M. Intra-articular morphine and saline injections induce release of large molecular weight proteoglycans into equine synovial fluid. Zentralbl Veterinarmed A. 1996; 43(3):147-53.

20. Elsharnouby NM, Eid HE, Abou Elezz NF, Moharram AN: Intraarticular injection of magnesium sulphate and/or bupivacaine for postoperative analgesia after arthroscopic knee surgery. Anesth Analg 2008, 106(5): 1548-1552, table of contents.

21. Baker JF, Walsh PM, Byrne DP, Mulhall KJ In vitro assessment of human chondrocyte viability after treatment with local anaesthetic, magnesium sulphate or normal saline. Knee Surg Sports Traumatol Arthrosc. 2011; 19(6):1043-6. 
22. Baker JF, Byrne DP, Walsh PM, Mulhall KJ. Human chondrocyte viability after treatment with local anesthetic and/or magnesium: results from an in vitro study. Arthroscopy. 2011;27(2):213-7.

23. Lee $\mathrm{CH}$, Wen ZH, Chang YC, Huang SY, Tang CC, Chen WF, Hsieh SP, Hsieh $\mathrm{CS}$, Jean $\mathrm{YH}$. Intra-articular magnesium sulfate (MgSO4) reduces experimental osteoarthritis and nociception: association with attenuation of $\mathrm{N}$-methyl-D-aspartate (NMDA) receptor subunit 1 phosphorylation and apoptosis in rat chondrocytes. Osteoarthritis Cartilage. 2009;17(11):1485-93.

24. Rosengren S, Boyle DL, Firestein GS. Acquisition, culture, and phenotyping of synovial fibroblasts. Methods Mol Med. 2007;135:365-75.

25. Ekman L, Nilsson G, Persson L, Lumsden JH. Volume of the synovia in certain joint cavities in the horse. Acta Vet Scand. 1981;22(1):23-31.

26. Lindegaard $\mathrm{C}$, Frost $\mathrm{AB}$, Thomsen $\mathrm{MH}$, Larsen $\mathrm{C}$, Hansen $\mathrm{SH}$, Andersen $\mathrm{PH}$. Pharmacokinetics of intra-articular morphine in horses with lipopolysaccharide-induced synovitis. Vet Anaesth Analg. 2010;37(2):186-95

27. Bassage LH, Ross MW. Diagnostic analgesia. In: Ross MW, Dyson SJ, editors. Diagnosis and management of lameness in the horse. 2nd ed. St. Louis, Missouri: Elsevier Saunders; 2011. p. 100-34.

28. Koltka K, Koknel-Talu G, Asik M, Ozyalcin S. Comparison of efficacy of intraarticular application of magnesium, levobupivacaine and lornoxicam with placebo in arthroscopic surgery. Knee Surg Sports Traumatol Arthrosc. 2011;19(11):1884-9.

29. Zeng C, Gao SG, Cheng L, Luo W, Li YS, Tu M, Tian J, Xu M, Zhang FJ, Jiang W, et al. Single-Dose Intra-Articular Morphine After Arthroscopic Knee Surgery: A Meta-Analysis of Randomized Placebo-Controlled Studies. Arthroscopy. 2013;29(8):1450-8.

30. Wintzer HJ, Fitzek A, Frey HH. Pharmacokinetics of procaine injected into the hock joint of the horse. Equine Vet J. 1981;13(1):68-9

31. Niles AL, Moravec RA, Riss TL. In vitro viability and cytotoxicity testing and same-well multi-parametric combinations for high throughput screening. Curr Chem Genomics. 2009:3:33-41.

32. Riss TL, Moravec RA, Niles AL, Benink HA, Worzella TJ, Minor L: Cell Viability Assays. In: Assay Guidance Manual. edn. Edited by Sittampalam GS, Coussens NP, Nelson H, Arkin M, Auld D, Austin C, Bejcek B, Glicksman M, Inglese J, Iversen PW et al. Bethesda (MD); 2004

33. Peffers M, Liu X, Clegg P. Transcriptomic signatures in cartilage ageing. Arthritis Res Ther. 2013:15(4):R98.

34. Livak KJ, Schmittgen TD. Analysis of relative gene expression data using real-time quantitative PCR and the 2(-Delta Delta C(T)) Method. Methods. 2001;25(4):402-8

35. Breu A, Rosenmeier K, Kujat R, Angele P, Zink W. The cytotoxicity of bupivacaine, ropivacaine, and mepivacaine on human chondrocytes and cartilage. Anesth Analg. 2013;117(2):514-22.

36. Grishko V, Xu M, Wilson G, Pearsall AW. Apoptosis and mitochondrial dysfunction in human chondrocytes following exposure to lidocaine, bupivacaine, and ropivacaine. J Bone Joint Surg Am. 2010;92(3):609-18.

37. Miyazaki T, Kobayashi S, Takeno K, Yayama T, Meir A, Baba H. Lidocaine cytotoxicity to the bovine articular chondrocytes in vitro: changes in cell viability and proteoglycan metabolism. Knee Surg Sports Traumatol Arthrosc. 2011;19(7):1198-205.

38. Bolt DM, Ishihara A, Weisbrode SE, Bertone AL. Effects of triamcinolone acetonide, sodium hyaluronate, amikacin sulfate, and mepivacaine hydrochloride, alone and in combination, on morphology and matrix composition of lipopolysaccharide-challenged and unchallenged equine articular cartilage explants. Am J Vet Res. 2008;69(7):861-7.

39. Eroglu A, Saracoglu S, Erturk E, Kosucu M, Kerimoglu S. A comparison of intraarticular morphine and bupivacaine for pain control and outpatient status after an arthroscopic knee surgery under a low dose of spinal anaesthesia. Knee Surg Sports Traumatol Arthrosc. 2010;18(11):1487-95.

40. Elkousy H, Kannan V, Calder CT, Zumwalt J, O'Connor DP, Woods GW. Intraarticular morphine versus bupivacaine for postoperative pain management. Orthopedics. 2013;36(9):e1121-7.

41. Bondok RS, Abd El-Hady AM. Intra-articular magnesium is effective for postoperative analgesia in arthroscopic knee surgery. Br J Anaesth. 2006; 97(3):389-92.

42. Stein A, Yassouridis A, Szopko C, Helmke K, Stein C. Intraarticular morphine versus dexamethasone in chronic arthritis. Pain. 1999:83(3):525-32

43. Bernardini D, Nasulewic A, Mazur A, Maier JA. Magnesium and microvascular endothelial cells: a role in inflammation and angiogenesis. Front Biosci. 2005;10:1177-82.
44. Nagai N, Fukuhata T, Ito Y, Tai H, Hataguchi Y, Nakagawa K. Preventive effect of water containing magnesium ion on paw edema in adjuvantinduced arthritis rat. Biol Pharm Bull. 2007;30(10):1934-7.

45. Salter DM, Wright MO, Millward-Sadler SJ. NMDA receptor expression and roles in human articular chondrocyte mechanotransduction. Biorheology. 2004;41(3-4):273-81.

46. Irwin W, Fontaine E, Agnolucci L, Penzo D, Betto R, Bortolotto S, Reggiani C, Salviati G, Bernardi P. Bupivacaine myotoxicity is mediated by mitochondria J Biol Chem. 2002;277(14):12221-7.

47. Syed HM, Green L, Bianski B, Jobe CM, Wongworawat MD. Bupivacaine and triamcinolone may be toxic to human chondrocytes: a pilot study. Clin Orthop Relat Res. 2011;469(10):2941-7.

48. Farkas B, Kvell K, Czompoly T, Illes T, Bardos T. Increased chondrocyte death after steroid and local anesthetic combination. Clin Orthop Relat Res. 2010; 468(11):3112-20.

49. Karpie JC, Chu CR. Lidocaine exhibits dose- and time-dependent cytotoxic effects on bovine articular chondrocytes in vitro. Am J Sports Med. 2007; 35(10):1621-7.

50. Chen Y, Zhang Y, Zhu YL, Fu PL. Efficacy and safety of an intra-operative intra-articular magnesium/ropivacaine injection for pain control following total knee arthroplasty. J Int Med Res. 2012;40(5):2032-40.

51. Chang X, Shen J, Yang H, Xu Y, Gao W, Wang J, Zhang H, He S. Upregulated expression of CCR3 in osteoarthritis and CCR3 mediated activation of fibroblast-like synoviocytes. Cytokine. 2016:77:211-9.

52. Bartok B, Firestein GS. Fibroblast-like synoviocytes: key effector cells in rheumatoid arthritis. Immunol Rev. 2010;233(1):233-55.

53. Gregory MH, Capito N, Kuroki K, Stoker AM, Cook JL, Sherman SL. A review of translational animal models for knee osteoarthritis. Arthritis. 2012:2012:764621.

\section{Submit your next manuscript to BioMed Central and we will help you at every step:}

- We accept pre-submission inquiries

- Our selector tool helps you to find the most relevant journal

- We provide round the clock customer support

- Convenient online submission

- Thorough peer review

- Inclusion in PubMed and all major indexing services

- Maximum visibility for your research

Submit your manuscript at www.biomedcentral.com/submit
) Biomed Central 